\title{
Victoria Ocampo, cronista outsider
}

María Celia Vázquez (2019).

Rosario, Beatriz Viterbo Editora; Ciudad Autónoma de Buenos Aires, Fundación Sur, 263 páginas. ISBN 978-950- 845-378-5.

\section{Q Ivonne Bordelois}

Victoria Ocampo fue una mujer vanidosa, autoritaria, prepotente, narcisista, snob, egocéntrica, ingenua, gorila, europeizante y fundamentalmente equivocada. Así la describen por mucho tiempo la crítica universitaria y sus correlatos, como el grupo de Contorno. También se suma la izquierda bienpensante, reacia a admitir la posibilidad de ningún liderazgo intelectual representado por una oligarca.

Voces más reposadas y reflexivas como las de Sarlo o Molloy comenzaron a dibujar matices más delicados en una figura tan monumental como desconcertante. Entre la oleada de nuevas investigadoras, el feminismo pionero de Victoria impone reservas ante la leyenda negra enarbolada por los apóstoles del progresismo crítico.

Victoria Ocampo era, según Octavio Paz, "no una figura mitológica sino una mujer dotada de generosidad, cólera e imaginación. Ha hecho lo que nadie había hecho antes en América"; según Lacan, en la dedicatoria de uno de sus libros, "A Victoria, mujer de este siglo, única"; según Cocteau, "Su belleza es una forma evidente del genio"; según Borges, "quizá, la mujer más eminente de este país"; según José Bianco, "la persona más inteligente que he conocido".

Tanto García Márquez como Vargas Llosa y Cortázar han atestiguado la importancia de SUR en su formación literaria, y su importancia y vigencia en la creación de una conciencia literaria latino americana; para Ricardo Piglia, se trata de una revista de la Generación del Ochenta, publicada con cincuenta años de atraso, plagada de excesos y provincianismos.

Todo esto significa que en una cultura y un país tan propensos a la autodestrucción como el nuestro, Victoria Ocampo es quizás el caso testigo por excelencia. Por eso no puede ser sino bienvenido un libro como el de María Celia Vázquez, que impone un espacio sereno e informado acerca del lugar que le corresponde a esta mujer única y torrencial, contradictoria y sobre todo mucho más compleja de lo que se ha sospechado hasta ahora.
Al llamar cronista a Victoria Ocampo, Vázquez no pretende disminuir sus dotes de escritora, que reconoce ampliamente, sino subrayar ante todo su voluntad de intervenir en los debates de su época, aun cuando al mismo tiempo se la califica también como outsider, ya que Ocampo nunca adoptó un periodismo profesional. Curiosa outsider, de todos modos, ya que Ocampo, a través de sus escritos, que ella define como Testimonios, intenta sobre todo darse a conocer como persona y, sobre todo, como mujer.

En la primera parte, “Espacios”, Vázquez señala la tensión en la que se encuentra Ocampo, enfrentada por un lado con ilustres visitantes extranjeros (Keyserling, Frank, Ortega) que intentan definiciones de lo nacional a partir del paisaje de la pampa -definiciones que Ocampo en parte cuestiona y en parte agradece, oponiéndose así a las protestas de los escritores nacionalistas que las impugnaban. Pero, por otro lado, Ocampo se ve expuesta a célebres interlocutores europeos que la tratan como sujeto exótico y subalterno, debatiéndose entre el deslumbramiento y la humillación. Así desfilan dos escritores, Paul Valéry y Virginia Woolf, sin duda luminarias de la literatura del siglo XX, representados por sus reacciones colonialistas ante las propuestas estéticas de Ocampo: el francés, incapaz de percibir la belleza de los cactus americanos; la inglesa, reduciendo el paisaje desconocido de la Argentina a un fulgor de mariposas imaginadas. A mi entender, es aquí donde el análisis de Vázquez alcanza una acuidad crítica muy superior a la de los previos comentarios sobre estos desencuentros. La sutileza con que Vázquez desentraña el pasaje de la admiración desmesurada de Victoria por Virginia a la instalación de una suerte de acrobacia teatral por la que Victoria acaba por calibrar la incapacidad de su anfitriona para descifrar sus diferencias, y le sigue el juego como cómplice, a la par que se burla de ella disfrazándose de sirena, esa sutileza es un festín inesperado de ironías y sonrisas no malévolas que bien demuestran hasta qué punto la supuesta ingenuidad de Ocampo y su cosmopolitismo incondicional no la privaban de brillar con un humor y una agudeza insólita en un diálogo donde sobreentendidos y malentendidos dan lugar 
finalmente a una lucidez deliciosa, que coloca a la escritora argentina en una onda de sofisticación equivalente a la de su ilustre interlocutora.

Menos entusiasmo por su pluma despierta el capítulo titulado "Litigios", donde Vázquez señala los enfrentamientos de Ocampo, primero con los adversarios externos -en las antípodas de su horizonte político, Hernández Arregui, que la lee y la cita equivocadamente, llevado por su hostilidad ideológica, mientras que Jauretche, mucho más generoso y comprensivo, recibe por lo menos la atención epistolar de una escritora que se siente respetada como tal por parte de su oponente, sin llegar a comprender del todo su autenticidad ni las implicaciones de sus críticas. Mucho más penoso en su contenido es el capítulo dedicado a los adversarios internos, donde la mala fe esgrimida contra Ocampo por Borges, su malevolencia y sus insidiosas malicias, el arbitrario maltrato infligido a figuras como Rabindranath Tagore, su ingratitud luego del desagravio ofrecido por Sur, son todas señales que hacen pensar, aun cuando Vázquez no lo explicite, que el desdén intelectual profesado por el faro de nuestras letras a su descubridora y poderosa mecenas encierra acaso, pese a los tardíos homenajes póstumos, un acendrado machismo y el angustioso desconcierto ante una figura mucho más vital que la suya.

El último capítulo, “Duelos”, explora el estilo y los sentidos de los obituarios que Ocampo dedica a Maeztu, su amiga y maestra feminista, y a Drieu La Rochelle, ex amante, talentoso escritor y lastimosa figura de las letras francesas, que se suicida, luego de finalizada la guerra, por la condena a sus actividades nazis. Aquí Ocampo, que siempre se declaró antifascista, enfrenta muy a su manera la obvia incorrección política y, en una apuesta lacerante, trata de salvar lo insalvable a través de una tortuosa representación donde aparecen mezclados el heroísmo de Nietzsche, el fariseísmo de Tartufo y la moral de Calígula.

Ejemplar por el volumen y la calidad de sus documentos y por su estilo equilibrado y convincente, pero aún más por la amplitud de su visión, que muy oportunamente viene a socavar los arraigados prejuicios con que gran parte de la intelligentzia académica ha intentado enterrar la imponente memoria de una mujer extraordinaria, el libro de María Celia Vázquez honra una de las virtudes más olvidadas de nuestra crítica literaria: la lealtad a la verdad y el coraje de llevar a la luz lo injustamente despreciado. 